\title{
IMPACT OF EXECUTIVE REMUNERATION AND FIRM LEVERAGE ON FIRM STABILITY: LESSONS FROM EUROPEAN FIRMS
}

\author{
Farjana Nasrin \\ Department of Business and Technology Management, Islamic University of \\ Technology, Bangladesh. \\ Email:farjana@iut-dhaka.edu Tel:01521220614
}

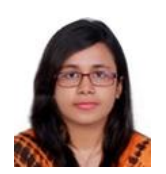

\section{Article History \\ Received: 18 November 2021 Revised: 20 December 2021 Accepted: 27 December 2021 Published: 3 January 2022}

\section{Keywords}

Zscore

Firms' stability

Executive remunerations

Firms' leverage

European context

Remuneration package.

\begin{abstract}
The aim of this study is to examine the impact of executive remuneration and firms' leverage on firms' stability as measured by winsorized Zscore (wZscore). The wZscore measure corresponds to the Altman Zscore, which increases as default risk decreases. To test the study's hypotheses, a linear regression model is applied to a 6-year panel dataset of 180 listed firms categorized in 10 economic sectors operating in 22 countries from the years 2013 to 2018. The results show that executive remuneration has a significant negative impact on firm stability as measured by wZscore. Additionally, firm leverage has a significant positive impact on firm stability. Beyond the theoretical implications, the findings of this study have some practical implications that are particularly relevant to boards of directors, shareholders, managers, and policymakers. The findings suggest that executives should be offered a proper remuneration package to maintain their firms' stability along with the capacity of firms' equity and assets to cope up with unprecedented circumstances and the firms' long-term debts. Finally, this study offers specific recommendations for how firms can balance their pay and performance in terms of executive remuneration and ensure better leverage to optimize their own and society's sustainable development.
\end{abstract}

Contribution/ Originality: This paper's primary contribution is to deepen the understanding of the impact of executive remuneration and firm leverage on firm stability. The findings suggest that a proper remuneration policy, board independence and maintaining a strong leverage over firms' equity and assets will contribute to firms' sustainable stability.

\section{INTRODUCTION}

Ensuring their stability is a major concern for all firms (De Jong, Zacharias, \& Nijssen, 2021). The stability of a firm depends on a number of issues, such as its financial strength, assets, equity, etc., as demonstrated by a number of previous studies (Bei \& Wijewardana, 2012; Keenan \& Aggestam, 2001). The stability of a firm refers to its ability to maintain a stable condition under any circumstances, without requiring adjustments to the firm's equity and resource capacity. Recently, the interest in understanding firms' stability by using Zscores has increased (Ali \& Azmi, 2016; Bai \& Elyasiani, 2013; Dwumfour, 2017; Emongor, Musau, \& Mwasiaji, 2020). In this study, the winsorized Zscore, which refers to how the measure of a firm's default risk corresponds to the Altman Zscore, is used as a measure of firms' stability (Agarwal \& Taffler, 2008; Altman, Iwanicz-Drozdowska, Laitinen, \& Suvas, 2017). Stakeholders need a measure of a firm's stability to be able to understand its impact on executive remuneration and the firm's leverage. 
The board of directors is responsible for ensuring a firm's stability, though it is challenging to manage unprecedented risks while maximizing the firm's strengths. Besides, employees' benefits, work responsibility and performance also contribute to the stability of a firm. Executive remuneration has a major impact on wZscore as a measure of stability because having a proper remuneration package including salary, bonuses, and performance appraisals motivates employees to work for the company's betterment (Nurun \& Dip, 2017; Thang \& Quang, 2005).

A firm's financial stability also depends on the firm's leverage, meaning the strength of equity to ensure better returns on assets. With increased leverage, a firm can manage its long-term debt with minimal liability (Valencia, 2014).

Based on the above considerations, this study aims to identify the impact of executive remuneration and firms' leverage on the stability of firms. This study employs a 6-year panel dataset from the years 2013 to 2018 of 180 listed firms across 10 economic sectors operating in 22 European countries. To get a proxy of firms' stability, wZscore is used to investigate the influence of executive remuneration and firms' leverage on stability. To identify the relationship, regression models are constructed based on a sample of European firms.

The empirical results demonstrate that executive remuneration has a significant negative effect on firms' stability as measured by wZscore, whereas firms' leverage has a significant positive impact on firms' stability. The remainder of this paper is organized as follows: section 2 provides the theoretical framework and literature review, section 3 describes the research methodology, section 4 describes the findings and analysis, and section 5 describes the conclusions and implications.

\section{LITERATURE REVIEW}

\subsection{Firm Stability and Executive Remuneration}

Executive remuneration refers to compensation of the board members for the performance of their duties in terms of salary or fees. The previous literature suggests that the relationship between a firm's stability and its executive remuneration remains inclusive because of the application of different empirical methods and theories (Aslam, Haron, \& Tahir, 2019; Rasoava, 2019). Elsayed and Elbardan (2018) found evidence of a strong influence of executive remuneration on firms' stability using the tournament theory of compensation; however, the study of Aslam et al. (2019) found only weak evidence for this link. Nonetheless, there is evidence of a significant association between executive compensation and firms' stability (Raithatha \& Komera, 2016) and a simultaneous relationship has been shown to exist between the two (Buachoom, 2017).

Additionally, a positive and significant association between firm stability and executives' remuneration has been demonstrated when the board size is larger (Al Farooque, Buachoom, \& Hoang, 2019; Hearn, 2013; Rehman, Ali, Hussain, \& Waheed, 2021). According to Elyasiani and Jia (2010), executive compensation is positively related to firm stability and performance through employee benefits. The studies of Sheikh, Shah, and Akbar (2018) and Smirnova and Zavertiaeva (2017) showed that CEO remuneration is positively correlated with firms' accounting performance and vice-versa.

On the one hand, Das and Dey (2016) found no evidence of a direct influence of executive compensation on firm stability, other than temporal issues (DesJardine \& Shi, 2021). Also, because compensation policies are based on share price, executive directors' remuneration has no direct relationship with firm performance (Kirsten \& Du, 2018). The authors Yamina and Mohamed (2017) revealed that compensation is linked to relatively improved financial performance, while bonus payments are linked to firms' accounting performance.

On the other hand, Bussin and Modau (2015) argued that the relationship between executive remuneration and firms' stability has been declining since the global financial crisis of 2008 due to executives' focus on enhancing their own remuneration. There exists a misaligned relationship between executive compensation benefits and company performance as well as firms' stability (Marimuthu \& Kwenda, 2019). However, Merhebi, Pattenden, Swan, and Zhou (2006) noted that the declining relationship between these two has occurred as the focus has moved 
away from short-term incentives. Studies have observed a negative impact of executive remuneration structure on firm stability (Chen \& Jermias, 2014). Also, the literature shows that executive directors' remuneration adversely affects firm stability when the lower rung of directors receives cash remuneration (Gill, 2014). Based on the outlined evidence from the literature, it can be concluded that executive remuneration has a negative impact on firm stability. Hence, the following hypothesis is proposed.

H1: Executive remuneration has a negative impact on a firm's stability

\subsection{Firm Stability and Firm Leverage}

Leverage refers the ratio of firms' long-term debt to total assets. More simply it means the use of owners' capital or borrowing funds to increase the returns of assets. The previous literature has shown inconclusive results regarding the relationship between firms' stability and leverage. No significant effect has been found of leverage on firm value regardless of moderating factors like eco-efficiency (Osazuwa \& Che-Ahmad, 2016). Jermias (2008) opined that factors like firms' strategic choices and managers' opportunistic behavior moderate the relationship between firm leverage and stability. A relationship between Zscore and firm leverage can be postulated in that increased leverage drives firms to take excessive risk (Bhagat, Bolton, \& Lu, 2015). Valencia (2014) found a relationship between banks' leverage and stability, as increased leverage helps to finance loans with limited liability.

In addition, there exists a non-monotonic relationship between leverage and firm stability as measured by cash holding. On the one hand, there is a significant non-linear relationship between these two, as by increasing their leverage, firms can accumulate cash holdings to minimize the risk of bankruptcy and financial distress. On the other hand, factors like ownership concentration, creditors, and shareholders' protection can have different effects on firms' stability (Guney, Ozkan, \& Ozkan, 2007). However, other studies have demonstrated a negative relationship between financial stability and leverage. During times of crisis, bank risk negatively impacts on financial stability where there is deposit insurance coverage (Anginer, Demirguc-Kunt, \& Zhu, 2014). On the one side, both explicit and implicit leverage are negatively related to firm stability by increasing individual risks and vulnerability to financial shocks. On the other side, reverse leverage is good for the health of individual banks but bad for financial stability (Papanikolaou \& Wolff, 2014). During financial crises, leverage has a negative impact on large firms' performance and stability (Vithessonthi \& Tongurai, 2015). Finally, Bei and Wijewardana (2012) found a positive relationship between financial leverage and a firm's financial growth though it gives a negative indication of the firm's future growth. There remains a positive moderating effect of capital intensity between leverage and financial distress when measured with the Zscore, as explained by Lee (2011). During financial crises, there is a positive relationship between these factors for small firms (Vithessonthi \& Tongurai, 2015). Based on the above literature and arguments, it can be concluded that a firm's leverage has a positive impact on firm stability. Hence, the following hypothesis can be developed.

H2: There is a positive relationship between a firm's stability and its leverage

\section{RESEARCH METHODOLOGY}

\subsection{Sample Selection and Data Sources}

The purpose of this study is to analyze the impact of executive remuneration and firm leverage on wZscore as a measure of firm stability. This study comprises a 6-year panel dataset from the years 2013 to 2018 of 180 listed firms categorized in 10 economic sectors operating in 22 countries.

The Thomson Reuters database has been used as the primary source of data. Other sources of information include the Global Gender Gap Index and World Governance Indicator from the World Economic Forum and World Bank respectively. The Global Gender Gap Index, introduced by the World Economic Forum, is a framework for capturing the magnitude of gender-based disparities and tracking their progress over time. The Worldwide Governance Indicators (WGI) report aggregate and individual governance indicators for over 200 
countries and territories over the period 1996-2021, for six dimensions of governance including voice and accountability, political stability, and governance effectiveness. In our empirical analysis, to minimize any potential bias in the results, some irrelevant information is removed, such as observations of non-European countries if the firm's headquarters are in Bermuda, Mexico, Singapore, the United States, Russia, the Faroe Islands or if the GICS Sector Code is 40.

\subsection{Variables Measurement}

In this study, we have used winsorized Zscore (wZscore) as the dependent variable to measure firm stability. Firm stability refers to the company's ability to cope with unprecedented circumstances with no significant changes to the company's assets. Here, wZscore is used as a proxy measure of firms' stability, meaning that firms' default risk corresponds to the Altman Zscore. A 6-year panel dataset has been used to test the hypotheses against the regression model. To identify whether executive remuneration and firm leverage can influence a firm's wZscore, several independent variables have been used in this study including, crucially, executive remuneration and firm leverage. Executive remuneration, an important independent variable in this study, refers to the compensation benefits of the executives of a firm in terms of salary, bonuses, shares, stocks and other financial compensation (Iqbal, Guohao, \& Akhtar, 2017) Firm leverage refers to a firm's capacity to maintain its long-term liabilities against its assets and equity (Eriotis, Vasiliou, \& Ventoura-Neokosmidi, 2007). In this empirical study, several control variables have been used in the regression model to minimize model misinterpretation, including gender diversity (participation of men and women on the board), board independence (independent board members), ownership (shareholders' ownership of firm), size of the firm (total assets), board size (total number of directors on board), board executive (number of executive members in board), and ROA (return on assets). Random effect and fixed effect regression models are constructed in this study, which use these control variables to better understand their influence on wZscore as a measure of firm stability.

\subsection{Methodology}

This study is based on panel data estimation using a fixed effect regression model. In our econometric model, there are several limitations caused by the unobserved heterogeneity problem (Gormley \& Matsa, 2014), which measures the time-invariant variables of each firm. Also, an endogeneity problem arises because of the causality relationship between certain independent variables (Roberts \& Whited, 2013; Wintoki, Linck, \& Netter, 2012). The measure of wZscore corresponds to the Altman Zscore, which increases as default risk decreases. Consequently, to gain a better understanding of the relationships among the dependent and independent variables in this model through multivariate analysis, wZscore has been multiplied by negative 1 (denoted as negwZscore). After checking all the variables to normalize their distribution, a regression model is run to understand the influence of these variables on firm stability. In this study, we have used a fixed effect model and a random effect model. Also, we have rejected the absence of firm-specific impact as a preliminary estimate, suggesting that ordinary least squared (OLS) calculations are inconsistent, and $\mathrm{FE}$ and $\mathrm{RE}$ estimations are more appropriate. The STATA command xtreg is suitable for panel-data linear models.

\section{Model:}

$$
\mathrm{Y}_{\mathrm{itc}}=\beta_{0}+\beta_{1} \text { Executive Remuneration }_{\text {itc }}+\beta_{2} \text { Firms }^{s} \text { Leverage }_{\text {ite }}+\sum_{\mathrm{j}=1}^{\tilde{j}} \text { Vj FLV }_{\text {itc }}+\varepsilon_{\mathrm{it}}
$$

Here, Y represents our alternative measure of negwZscore as the dependent variable which measures firm stability. Executive remuneration and firms' leverage are the two independent variables. FLV refers to the firm 
level control variables $\mathrm{J}=7$, corresponding to gender diversity, firm size, board size, board independence, board executive, shareholders' ownership and return on assets. And zit is the stochastic error term.

\section{RESULT AND ANALYSIS}

\subsection{Multivariate Analysis}

Table 1 shows the empirical findings that are used to test the hypotheses about the impact of executive remuneration and firm leverage on negwZscore as a measure of firm stability. Executive remuneration, according to hypothesis 1, has a negative impact on a firm's stability (negwZscore). The result is statistically significant with upside down and U-shaped relationships under both the fixed and random effect models.

This U-shaped relationship between executive remuneration and firm stability indicates the contradictory connection. Specifically, the result states that a firm becomes more stable when it offers good remuneration, but that after a certain point increased remuneration causes the stability of the firm to decrease. The reason behind this relationship might be the motivation level of executives to achieve stability of the firm's assets and debt payment.

Table 1. Multivariate analysis.

\begin{tabular}{|c|c|c|}
\hline Variables & $(1)(f e)$ & (2) (re) \\
\hline & negwZscore & negwZscore \\
\hline \multirow[t]{2}{*}{ GrDivers 1} & 0.156 & 0.207 \\
\hline & $(0.653)$ & 0.616 \\
\hline \multirow[t]{2}{*}{ BRemun5 } & $3.462^{* * * *}$ & $2.320^{*} * *$ \\
\hline & $(0.664)$ & $(0.618)$ \\
\hline \multirow[t]{2}{*}{ c.BRemun5\#c.BRemun5 } & $-0.133^{* * * *}$ & $-0.0926^{* * * *}$ \\
\hline & $(0.0268)$ & $(0.0254)$ \\
\hline \multirow[t]{2}{*}{ BIndependent } & -0.0311 & -0.178 \\
\hline & $(0.438)$ & $(0.426)$ \\
\hline \multirow[t]{2}{*}{ Own 1} & -0.477 & -0.540 \\
\hline & $(0.428)$ & $(0.389)$ \\
\hline \multirow[t]{2}{*}{ Size } & 0.126 & 0.0527 \\
\hline & $(0.189)$ & $(0.0985)$ \\
\hline \multirow[t]{2}{*}{ BSize 1} & -0.00457 & -0.0449 \\
\hline & $(0.0446)$ & $(0.0396)$ \\
\hline \multirow[t]{2}{*}{ BExecutive } & $-1.351^{*}$ & $-1.217^{*}$ \\
\hline & $(0.746)$ & $(0.712)$ \\
\hline \multirow[t]{2}{*}{ wroa } & $-2.539 * * *$ & $-4.405^{* * * *}$ \\
\hline & $(0.883)$ & $(0.873)$ \\
\hline \multirow[t]{2}{*}{ leverage 1} & $4.653^{*} * * *$ & $4.915^{* * * *}$ \\
\hline & $(0.587)$ & $(0.520)$ \\
\hline \multirow[t]{2}{*}{ Constant } & $-28.079 * * *$ & $-18.181 * * *$ \\
\hline & $(5.178)$ & $(3.813)$ \\
\hline Observations & 558 & 558 \\
\hline Number of Iden & 125 & 125 \\
\hline R-squared & 0.231 & 0.210 \\
\hline
\end{tabular}

Hypothesis 2 states that a firm's leverage has a statistically significant positive impact on that firm's stability (negwZscore). The results show that firm stability increases with an increase of firm leverage. Specifically, the capacity of a firm to pay their debts increases with a stable asset and equity measurement in both the fixed and random effect models. Regarding the control variables, the results are in line with several previous studies (Harymawan \& Nowland, 2016; Marsili, 2006; Mas-Ruiz \& Ruiz-Moreno, 2011); firm size has a positive impact on firm stability, meaning that a firm's stability increases when its size increases. Gender diversity on the board also has a positive impact on firms' stability, a fact which is also supported by a number of studies (Attah-Boakye, Adams, Kimani, \& Ullah, 2020; Dwyer, Richard, \& Chadwick, 2003; Fernando, Jain, \& Tripathy, 2020). Gender diversity on the board can lead to more appropriate board decisions being made, boosting the firm's competitive 
profile and performance as well as its stability (Romano, Cirillo, Favino, \& Netti, 2020). On the other hand, board size, board independence, and board executive are shown to have a negative impact on firms' stability. A larger board may cause undue complexity and inefficiency in its operations (Adeabah, Gyeke-Dako, \& Andoh, 2018; Linck, Netter, \& Yang, 2008). As a result, firms' overall stability might suffer under a larger board. Also, shareholders' ownership of a firm negatively influences firm stability as measured by negwZscore. The reason is that, when a firm's ownership is more concentrated in its shareholders it can cause conflict between satisfying their personal interests and the proper focus on improving the firm's stability. However, return on assets (ROA) also has a significant negative impact on firms' stability. The reason may be that companies that fail to generate good profit on their assets or through investment create less revenue growth. Firms can achieve sustainable stability by increasing their focus on asset investment and secured cash conversion policies (Rostami, Rostami, \& Kohansal, 2016; Takon, 2013). Finally, this empirical study recommends that firms increase their stability by addressing a number of issues such as board size, independence, firms' ownership, firms' size, executive remuneration, return on assets and others. Proper policy implementation of asset investment, board independence management, shareholders' ownership, and remuneration policies can make firms' stability more sustainable.

\section{CONCLUSIONS AND IMPLICATIONS}

This study has examined the impact of executive remuneration and firm leverage on firm stability measured by negwZscore using an empirical approach. Previous studies have shown that executive remuneration and firm leverage have a significant influence on the stability of a firm. This study examined a sample of 180 listed European firms for which a 6-year panel dataset for the years 2013 to 2018 was constructed. This study has found that firm stability, as measured by wZscore and then multiplied by negative 1 to facilitate understanding, is impacted by both executive remuneration and firm leverage to a degree that is statistically significant. Executive remuneration is significantly and negatively related to firm stability, displaying a U-shaped relationship. That means that when executive remuneration increases, firm stability improves up to a certain point, after which excessive remuneration and other compensation benefits lead to a decrease in firm stability due to executives' reluctant and sluggish attitudes. However, inadequate remuneration and compensation benefits cause executives to be unwilling to perform their jobs properly. Rather, a properly balanced executive remuneration package will increase the firm's stability as measured by the negwZscore. In addition, the other important finding of this study is that firm leverage is significantly and positively correlated with firm stability as measured by negwZscore. This finding states that when firm leverage is good, firms also become more stable, as a firm's stability increases with an increase in its leverage. As a result, a firm will be able to cover its long-term debt with its equity and assets in times of unprecedented circumstances. However, our empirical study has not investigated data from non-European firms, emerging economies and other countries. Also, the significance of other variables that may influence firms' stability is not explained here. The use of a larger sample might add some interesting implications in this regard. Finally, data availability remains an issue for investigations of this type.

Funding: This study received no specific financial support.

Competing Interests: The author declares that there are no conflicts of interests regarding the publication of this paper.

\section{REFERENCES}

Adeabah, D., Gyeke-Dako, A., \& Andoh, C. (2018). Board gender diversity, corporate governance and bank efficiency in Ghana: A two-stage data envelope analysis (DEA) approach. Corporate Governance: The International Journal of Business in Society, 19(2), 299-320. Available at: https://doi.org/10.1108/cg-08-2017-0171.

Agarwal, V., \& Taffler, R. (2008). Comparing the performance of market-based and accounting-based bankruptcy prediction models. Journal of Banking Eீ Finance, 32(8), 1541-1551. Available at: https://doi.org/10.1016/j.jbankfin.2007.07.014. 
Al Farooque, O., Buachoom, W., \& Hoang, N. (2019). Interactive effects of executive compensation, firm performance and corporate governance: Evidence from an Asian market. Asia Pacific Journal of Management, 36(4), 111 1-1164. Available at: https://doi.org/10.1007/s10490-018-09640-2.

Ali, M., \& Azmi, W. (2016). Religion in the boardroom and its impact on Islamic banks' performance. Review of Financial Economics, 31, 83-88. Available at: https://doi.org/10.1016/j.rfe.2016.08.001.

Altman, E. I., Iwanicz-Drozdowska, M., Laitinen, E. K., \& Suvas, A. (2017). Financial distress prediction in an international context: A review and empirical analysis of Altman's Z-score model. Journal of International Financial Management $\mathcal{E}^{\circ}$ Accounting, 28(2), 131-171. Available at: https://doi.org/10.1111/jifm.12053.

Anginer, D., Demirguc-Kunt, A., \& Zhu, M. (2014). How does deposit insurance affect bank risk? Evidence from the recent crisis. Journal of Banking \& Finance, 48, 312-321. Available at: https://doi.org/10.1016/j.jbankfin.2013.09.013.

Aslam, E., Haron, R., \& Tahir, M. N. (2019). How director remuneration impacts firm performance: An empirical analysis of executive director remuneration in Pakistan. Borsa Istanbul Review, 19(2), 186-196. Available at: https://doi.org/10.1016/j.bir.2019.01.003.

Attah-Boakye, R., Adams, K., Kimani, D., \& Ullah, S. (2020). The impact of board gender diversity and national culture on corporate innovation: A multi-country analysis of multinational corporations operating in emerging economies. Technological Forecasting and Social Change, 161, 120247. Available at: https://doi.org/10.1016/j.techfore.2020.120247.

Bai, G., \& Elyasiani, E. (2013). Bank stability and managerial compensation. Journal of Banking \& Finance, 37(3), 799-813. Available at: https://doi.org/10.1016/j.jbankfin.2012.10.026.

Bei, Z., \& Wijewardana, W. P. (2012). Financial leverage, firm growth and financial strength in the listed companies in Sri Lanka. Procedia-Social and Behavioral Sciences, 40, 709-715. Available at: https://doi.org/10.1016/j.sbspro.2012.03.253.

Bhagat, S., Bolton, B., \& Lu, J. (2015). Size, leverage, and risk-taking of financial institutions. Journal of Banking \& Finance, 59, 520-537. Available at: https://doi.org/10.1016/j.jbankfin.2015.06.018.

Buachoom, W. (2017). Simultaneous relationship between performance and executive compensation of Thai non-financial firms. Asian Review of Accounting, 25(3), 404-423. Available at: https://doi.org/10.1 108/ara-02-2016-0020.

Bussin, M., \& Modau, M. F. (2015). The relationship between Chief executive officer remuneration and financial performance in South Africa between 2006 and 2012. SA Journal of Human Resource Management, 13(1), 1-18. Available at: https://doi.org/10.4102/sajhrm.v 13i1.668.

Chen, Y., \& Jermias, J. (2014). Business strategy, executive compensation and firm performance. Accounting \& Finance, 54(1), 113-134. Available at: https://doi.org/10.1111/j.1467-629x.2012.00498.x.

Das, A., \& Dey, S. (2016). Role of corporate governance on firm performance: A study on large Indian corporations after implementation of companies' act 2013. Asian Journal of Business Ethics, 5(1-2), 149-164. Available at: https://doi.org/10.1007/s13520-016-0061-7.

De Jong, A., Zacharias, N. A., \& Nijssen, E. J. (202 1). How young companies can effectively manage their slack resources over time to ensure sales growth: The contingent role of value-based selling. Journal of the Academy of Marketing Science, 49(2), 304-326. Available at: https://doi.org/10.1007/s11747-020-00746-y.

DesJardine, M. R., \& Shi, W. (2021). How temporal focus shapes the influence of executive compensation on risk taking. Academy of Management Journal, 64(1), 265-292. Available at: https://doi.org/10.5465/amj.2018.1470.

Dwumfour, R. A. (2017). Explaining banking stability in Sub-Saharan Africa. Research in International Business and Finance, 41, 260-279. Available at: https://doi.org/10.1016/j.ribaf.2017.04.027.

Dwyer, S., Richard, O. C., \& Chadwick, K. (2003). Gender diversity in management and firm performance: The influence of growth orientation and organizational culture. Journal of Business Research, 56(12), 1009-1019. Available at: https://doi.org/10.1016/s0148-2963(01)00329-0.

Elsayed, N., \& Elbardan, H. (2018). Investigating the associations between executive compensation and firm performance: Agency theory or tournament theory. Journal of Applied Accounting Research, 19(2), 245-270. Available at: https://doi.org/10.1108/jaar-03-2015-0027. 
Elyasiani, E., \& Jia, J. (2010). Distribution of institutional ownership and corporate firm performance. Journal of Banking \& Finance, 34(3), 606-620. Available at: https://doi.org/10.1016/j.jbankfin.2009.08.018.

Emongor, E., Musau, S., \& Mwasiaji, E. (2020). Non-interest income and insolvency risk of commercial banks in Kenya. Journal of Finance and Accounting, 4(5), 41-54.

Eriotis, N., Vasiliou, D., \& Ventoura-Neokosmidi, Z. (2007). How firm characteristics affect capital structure: An empirical study. Managerial Finance, 33(5), 321-331. Available at: https://doi.org/10.1108/03074350710739605.

Fernando, G. D., Jain, S. S., \& Tripathy, A. (2020). This cloud has a silver lining: Gender diversity, managerial ability, and firm performance. Journal of Business Research, 117, 484-496. Available at: https://doi.org/10.1016/j.jbusres.2020.05.042.

Gill, S. (2014). Rewards for failure: An explanation for anomalous executive remuneration. Journal of Indian Business Research, 6(2), 90-127. Available at: https://doi.org/10.1108/jibr-05-2013-0054.

Gormley, T. A., \& Matsa, D. A. (2014). Common errors: How to (and not to) control for unobserved heterogeneity. The Review of Financial Studies, 27(2), 617-661. Available at: https://doi.org/10.1093/rfs/hht047.

Guney, Y., Ozkan, A., \& Ozkan, N. (2007). International evidence on the non-linear impact of leverage on corporate cash holdings. Journal of Multinational Financial Management, 17(1), 45-60. Available at: https://doi.org/10.1016/j.mulfin.2006.03.003.

Harymawan, I., \& Nowland, J. (2016). Political connections and earnings quality: How do connected firms respond to changes in political stability and government effectiveness? International Journal of Accounting E Information Management, 24(4), 339-356. Available at: https://doi.org/10.1108/ijaim-05-2016-0056.

Hearn, B. (2013). The determinants of director remuneration in West Africa: The impact of state versus firm-level governance measures. Emerging Markets Review, 14, 11-34. Available at: https://doi.org/10.1016/j.ememar.2012.11.004.

Iqbal, S., Guohao, L., \& Akhtar, S. (2017). Effects of job organizational culture, benefits, salary on job satisfaction ultimately affecting employee retention. Review of Public Administration and Management, 5(3), 1-7. Available at: https://doi.org/10.4172/2315-7844.1000229.

Jermias, J. (2008). The relative influence of competitive intensity and business strategy on the relationship between financial leverage and performance. The British Accounting Review, 40(1), 71-86. Available at: https://doi.org/10.1016/j.bar.2007.11.001.

Keenan, J., \& Aggestam, M. (2001). Corporate governance and intellectual capital: Some conceptualisations. Corporate Governance: An International Review, 9(4), 259-275. Available at: https://doi.org/10.1111/1467-8683.00254.

Kirsten, E., \& Du, T. E. (2018). The relationship between remuneration and financial performance for companies listed on the Johannesburg Stock Exchange. South African Journal of Economic and Management Sciences, 21(1), 1-10. Available at: https://doi.org/10.4102/sajems.v21i1.2004.

Lee, S. (2011). Moderating effects of capital intensity on the relationship between leverage and financial distress in the US restaurant industry. The Journal of Hospitality Financial Management, 19(1), 127-127.

Linck, J. S., Netter, J. M., \& Yang, T. (2008). The determinants of board structure. Journal of Financial Economics, 87(2), 308-328. Available at: https://doi.org/10.1016/j.jfineco.2007.03.004.

Marimuthu, F., \& Kwenda, F. (2019). The relationship between executive remuneration and financial performance in South African State-owned entities. Academy of Accounting and Financial Studies Journal, 23(4), 1-18.

Marsili, O. (2006). Stability and turbulence in the size distribution of firms: Evidence from Dutch manufacturing. International Review of Applied Economics, 20(2), 255-272. Available at: https://doi.org/10.1080/02692170600581193.

Mas-Ruiz, F., \& Ruiz-Moreno, F. (2011). Rivalry within strategic groups and consequences for performance: The firm-size effects. Strategic Management Journal, 32(12), 1286-1308. Available at: https://doi.org/10.1002/smj.936.

Merhebi, R., Pattenden, K., Swan, P. L., \& Zhou, X. (2006). Australian chief executive officer remuneration: Pay and performance. Accounting $\mathcal{E}^{2}$ Finance, 46(3), 481-497. Available at: https://doi.org/10.1111/j.1467-629x.2006.00178.x.

Nurun, N. I. M., \& Dip, T. H. A. (2017). Impact of motivation on employee performances: A case study of Karmasangsthan bank Limited, Bangladesh. Arabian Journal of Business and Management Review, 7(293), 2. 
Osazuwa, N. P., \& Che-Ahmad, A. (2016). The moderating effect of profitability and leverage on the relationship between ecoefficiency and firm value in publicly traded Malaysian firms. Social Responsibility Journal, 12(2), 295-306. Available at: https://doi.org/10.1108/srj-03-2015-0034.

Papanikolaou, N. I., \& Wolff, C. C. (2014). The role of on-and off-balance-sheet leverage of banks in the late 2000s crisis. Journal of Financial Stability, 14, 3-22. Available at: https://doi.org/10.1016/j.jfs.2013.12.003.

Raithatha, M., \& Komera, S. (2016). Executive compensation and firm performance: Evidence from Indian firms. IIMB Management Review, 28(3), 160-169. Available at: https://doi.org/10.1016/j.iimb.2016.07.002.

Rasoava, R. (2019). Executive compensation and firm performance: A non-linear relationship. Problems and Perspectives in Management, 17(2), 1-17. Available at: https://doi.org/10.21511/ppm.17(2).2019.01.

Rehman, A. u., Ali, T., Hussain, S., \& Waheed, A. (2021). Executive remuneration, corporate governance and corporate performance: Evidence from China. Economic Research, 1-26. Available at: https://doi.org/10.1080/1331677x.2020.1867214.

Roberts, M. R., \& Whited, T. M. (2013). Endogeneity in empirical corporate finance1 Handbook of the Economics of Finance (Vol. 2, pp. 493-572): Elsevier.

Romano, M., Cirillo, A., Favino, C., \& Netti, A. (2020). ESG (Environmental, Social and Governance) Performance and board gender diversity: The moderating role of CEO duality. Sustainability, 12(21), 9298. Available at: https://doi.org/10.3390/su12219298.

Rostami, S., Rostami, Z., \& Kohansal, S. (2016). The effect of corporate governance components on return on assets and stock return of companies listed in Tehran stock exchange. Procedia Economics and Finance, 36, 137-146. Available at: https://doi.org/10.1016/s2212-5671(16)30025-9.

Sheikh, M. F., Shah, S. Z. A., \& Akbar, S. (2018). Firm performance, corporate governance and executive compensation in Pakistan. Applied Economics, 50(18), 2012-2027. Available at: https://doi.org/10.1080/00036846.2017.1386277.

Smirnova, A. S., \& Zavertiaeva, M. A. (2017). Which came first, CEO compensation or firm performance? The causality dilemma in European companies. Research in International Business and Finance, 42, 658-673. Available at: https://doi.org/10.1016/j.ribaf.2017.07.009.

Takon, S. M. (2013). Does cash conversion cycle have impact on return on assets of Nigerian firms. Research Journal of Finance and Accounting, 4(14), 34-42.

Thang, L. C., \& Quang, T. (2005). Human resource management practices in a transitional economy: A comparative study of enterprise ownership forms in Vietnam. Asia Pacific Business Review, 11(1), 25-47. Available at: https://doi.org/10.1080/1360238052000298362.

Valencia, F. (2014). Monetary policy, bank leverage, and financial stability. Journal of Economic Dynamics and Control, 47, $20-38$. Available at: https://doi.org/10.1016/j.jedc.2014.07.010.

Vithessonthi, C., \& Tongurai, J. (2015). The effect of firm size on the leverage-performance relationship during the financial crisis of 2007-2009. Journal of Multinational Financial Management, 29, 1-29. Available at: https://doi.org/10.1016/j.mulfin.2014.11.001.

Wintoki, M. B., Linck, J. S., \& Netter, J. M. (2012). Endogeneity and the dynamics of internal corporate governance. Journal of Financial Economics, 105(3), 581-606. Available at: https://doi.org/10.1016/j.jfineco.2012.03.005.

Yamina, A., \& Mohamed, B. (2017). The impact of firm performance on executive compensation in France. Mediterranean Journal of Social Sciences, 8(2), 63-69. Available at: https://doi.org/10.5901/mjss.2017.v8n2p63.

Views and opinions expressed in this article are the views and opinions of the author(s), Journal of Asian Business Strategy shall not be responsible or answerable for any loss, damage or liability etc. caused in relation to/arising out of the use of the content. 